Cadernos de

Pesquisa do CDHIS

\title{
Vir a Ser Outro por Meio das Narrativas do Vivido
}

\author{
Becoming Another Through the Narratives of the Lived
}

Marcemino Bernardo Pereira ${ }^{1}$

\footnotetext{
${ }^{1}$ Professor de História na EMEF "Pe. Melico Cândido Barbosa" - SME de Campinas, SP; Doutor em Educação pela UNICAMP.
} 


\section{RESUMO}

Este trabalho narra experiências de um professor de História do Ensino Fundamental na rede municipal de Campinas - SP. São histórias amparadas em lembranças, produções de alunos e registros de aula do autor e que dialogam, basicamente, com as reflexões de Walter Benjamin sobre a memória e a escrita narrativa. Trata-se de uma investigação no campo da educação narrada em primeira pessoa, problematizando o ensino de história por meio de documentos e escrita de textos de opinião, bem como os percursos formativos do professor. As várias histórias aqui narradas se entretecem na construção de sentidos para prática docente que emergem à medida que se conta, produzindo saberes entendidos como lições do vivido.

Palavras-chave: Pesquisa narrativa; Ensino de história; Saberes docentes; Saberes da experiência; Alteridade.

\section{ABSTRACT}

This work narrates the experiences of a history teacher of elementary education in the municipal network of Campinas - SP. They are stories based on memories, student productions and class records of the author and that dialogue, basically, with Walter Benjamin's reflections on memory and narrative writing. This is an investigation in the field of education narrated in the first person, problematizing the teaching of history through documents and writing of opinion texts, as well as the formative paths of the teacher. The various stories narrated here interweave in the construction of meanings for teaching practice that emerge as one tells, producing knowledge understood as lessons from the experience.

Keywords: Narrative research; History teaching; Teaching knowledge; Knowledge of experience; Alterity. 
O que necessitamos talvez não seja uma língua que nos permita objetivar o mundo, uma língua que nos dê a verdade do que são as coisas, e sim uma língua que nos permita viver no mundo, fazer a experiência do mundo, e elaborar com outros o sentido (ou a ausência de sentido) do que nos acontece. (Jorge Larrosa, 2014, P. 65)

A narrativa que se vai ler aqui toma como base de consulta e construção duas pesquisas anteriores em educação, no campo da formação continuada, que por sua vez também foram produzidas como narrativas em primeira pessoa ${ }^{2}$. Ambas são escritas de experiências do vivido (LIMA; João W. GERALDI; Corinta M. G. GERALDI 2015) e foram construídas por meio de pesquisa em documentos de arquivos pessoais/profissionais, bem como a partir de lembranças e rememorações.

As centenas de registros de diversas naturezas produzidos por alunos e professores nas salas de aula, ou seja, em função de uma atividade, quando se acumulam ao longo do tempo nas gavetas e armários privados, configuram-se como arquivos pessoais. A guarda desses documentos se dá por razões extremas, num dos polos a necessidade comum que se encontra na base mesmo das origens do arquivo: a comprovação de um ato institucional, a "prova" do rendimento escolar do aluno, suporte das certificações; no outro polo está um gesto de afeto: um bilhete recebido, as fotos de uma festa, registros que despertam lembranças.

Por meio da variedade dos registros/documentos que transitam entre estes dois extremos, torna-se possível reconstruir metodicamente os percursos formativos de alunos e professores, e visto que o arquivo "não é coincidente com a memória" (TESSITORE, 2017: 26), essa reconstrução metódica torna-se

\footnotetext{
2 Para um breve histórico dessa modalidade de pesquisa em educação no Brasil, além de uma discussão fundamental dos seus pressupostos teórico metodológicos e uma distinção de suas diversas possibilidades, conferir LIMA, GERALDI e GERALDI (2015).
} 
também uma reconstrução dos próprios sujeitos quando tais documentos são lidos na sua relação dialógica; recontextualiza a sua produção ao revelar novos sentidos até então latentes, que apenas se insinuam nas memórias dos envolvidos.

Foi esse o interesse das pesquisas que empreendi: compreender processos de ensino/aprendizado na sala de aula para além do currículo prescrito e programas bem intencionados, aprender a ver e ouvir situações de aprendizagens que envolvem alunos e professores num único movimento de transformação.

Fica a advertência que apesar de tratar-se da retomada de duas pesquisas anteriores, esta nova escrita não se ampara numa solução do tipo comentário sobre outra escrita ou recorte atualizado de um texto maior, a dialógica da narrativa não permite esse caminho seguro. Está mais para a retomada de uma história que não termina, onde quem conta sempre aumenta um ponto. Isso não quer dizer, absolutamente, que as histórias narradas nas escritas anteriores serão aqui falseadas ou negadas, mas entretecidas de outro modo, o que, certamente, produzirá novos sentidos para quem conta.

É uma história curta - talvez um conto -, parte das minhas aventuras como professor de História no ensino fundamental, da qual sou naturalmente o herói, mas que, como toda trama, só se faz na presença de outros personagens que, no caso dessa escrita, se alternam no protagonismo. Talvez seja uma história meio sem graça, sem grandes reviravoltas que possam prender a atenção do leitor, e não tem como ter um final feliz porque sequer termina - até porque ainda estou vivo e jamais poderei contar o final da minha história. Só você poderá dizer se valeu a pena ter dispensado tempo para acompanhá-la.

Estávamos nos inícios dos anos 90 do século passado, ainda impulsionados pelos ventos da redemocratização recente e eu acabava de chegar a Campinas, grande cidade do interior paulista para lecionar História na 
rede pública. Recém-formado em História e vindo de uma cidade pequena da longínqua região noroeste do Estado, era a oportunidade de encontrar aulas livres em quantidade suficiente para sobreviver como professor, além de outras possibilidades de formação. O clima geral de redemocratização inflava o meu entusiasmo em participar de algum modo daqueles tempos tão marcados por esperanças de transformações políticas e sociais, esperanças que eu trazia muito bem acompanhadas de alguns livros, entre eles Educação e Mudança, de Paulo Freire, com prefácio do Prof. Moacir Gadotti, e Os Aparelhos Ideológicos de $E_{s t a d o}$, de Louis Althusser, em uma cópia encadernada, lidos e relidos, com dezenas de trechos grifados que eu tomava como máximas: as minhas tremulantes bandeiras (ou, quem sabe, lanças de ataque aos moinhos de vento).

Assumi algumas aulas livres em uma escola da rede estadual na periferia, no então Primeiro Grau noturno, com algumas aulas também em uma unidade do Supletivo que ficava a poucas quadras. Trabalhei nessa escola por cinco anos, mas não trago muitas lembranças, como se tudo o que passei ali fizesse parte da minha infância docente. Já se passaram quase trinta anos. Há uma delas, uma lembrança, porém, que me acompanhou por algum tempo.

Eu dividia as aulas do período noturno com uma colega que estava na escola há mais tempo e era efetiva no cargo. Já em dezembro, muito próximo do encerramento do ano letivo, enquanto arrumava o meu material no armário da sala dos professores, entra esta minha colega, apressada, com os dedos ainda sujos do pó de giz e lança, com veemência, o livro didático sobre a mesa, fazendo emergir uma leve e rarefeita nuvenzinha branca. Olha para mim e afirma, com a satisfação dos vitoriosos, para si mesma: Acabei!!!

Esse é o tipo de lembrança que se carrega como acontecimento memorável, que delimita fronteiras e por isso merece ser guardada na

\footnotetext{
3 Ao contrário deste texto de FREIRE (1983), que ainda mantenho em meio aos outros livros, não localizei a cópia encadernada da obra de Althusser, deve ter se perdido ao longo desse tempo.
} 
sobriedade da carteira, junto aos outros documentos que nos identificam. Naqueles anos iniciais de magistério retive essa recordação enquanto sinal de advertência para o professor que eu não queria me tornar. Aqueles eram tempos de renovação dos manuais de História, mas na prática o ensino ainda se guiava por obras que contavam a construção do Estado e da Nação por meio das ações heroicas dos grandes Homens, em torno de fatos muito bem construídos e delimitados. Para mim, que colocava como perspectiva a formação de alunos críticos, apoiar-me exclusivamente nos usos do livro didático e na sua lógica de transmissão tecnicista, e ao mesmo tempo contar uma história tão estruturada pela ideologia dominante, significava reproduzir uma cultura alienante, falar por meio das palavras do opressor. Daí a força daquele acontecimento aparentemente tão banal, a ponto de ter permanecido em mim em constate diálogo com o que eu fazia.

Após cinco anos deixei a rede estadual para permanecer apenas na rede municipal, onde já vinha trabalhando há algum tempo e estava experimentando um tipo de formação muito diferente do que eu tinha tido até então, geralmente encontros restritos aos períodos de planejamento no início do ano: na rede municipal, os próprios professores se organizavam em grupos de estudos para discutir, trocar ideias e produzir material, num movimento que favorecia um repensar constante sobre a prática ${ }^{4}$, numa perspectiva que pensa a educação na relação teoria/prática (LARROSA, 2014), e em consequência a propõe como práxis reflexiva. Eu me sentia muito bem situado como professor crítico, guiado

\footnotetext{
4 "Estes grupos, que já existiam em algumas escolas municipais, começaram a ser remunerados durante a administração petista, entre 1989 e 1992, e esta decisão que pode ser entendida como parte do ideário daquele governo, voltado para o desenvolvimento da autonomia das unidades educacionais e a profissionalização dos trabalhadores da educação. Cada disciplina se reunia num dia da semana, e neste dia, não eram atribuídas aulas ao professor, para que ele pudesse participar. Os encontros dos professores de história aconteciam às quintas-feiras e eu estive participando regularmente até 1995." (PEREIRA, 2008, p. 98)
} 
por aquela lembrança/advertência de cinco, seis anos atrás, guardada com zelo na carteira, até que me ocorreu um encontro que abalou esta minha auto representação.

Este encontro se deu com uma ex-aluna da primeira escola em que lecionei, exatamente aquela mesma escola de onde eu guardava a preciosa lembrança do desejo de me tornar um professor diferente, que faz a diferença na vida dos alunos:

Já estava anoitecendo e eu voltava do trabalho. Ao sair do Terminal Central de ônibus de Campinas, do meio do fluxo apressado de rostos um se sobressai e sorrindo vem em minha direção, ganha contornos na penumbra e vejo uma mulher jovem, com uma criança nos braços de um lado, sacolas do outro. Ofegante, pela pressa e pelo peso, me cumprimenta e diz logo em seguida, como se estivesse me procurando há tempos para dar um recado: Nunca mais me esqueci do Tutankhamon!!

Jamais esperei ouvir aquilo. Do meio da multidão ressurgia o nome do Faraó como uma aparição. Foi a única frase dela, eu devo ter respondido algo como: Ah! Que bom...- não tinha muito o que falar.

Foi difícil acreditar que ela falava de mim, eu não lembrava de mim da maneira como ela se lembrava. Foi um desencontro de lembranças.

Antes de continuar, é preciso fazer um esclarecimento quanto ao sentido da palavra "lembrança" que estou usando aqui, essas imagens que se destacam na paisagem geral da memória. Trago-as no sentido de rememoração, do modo como foi proposto por Walter Benjamin em vários escritos e comentado por GAGNEBIN (1999; 2014).

Contar como a gente vem a ser o que a gente é, ou porque a gente faz algo do jeito que faz, com o devido cuidado de não se deixar cair nas armadilhas de uma subjetividade que sempre nos confirma, exige procedimentos do pensar que leve em conta a rememoração, revestida de 
sensibilidade, de cores e formas que mudam. É preciso aqui estabelecer a devida distância entre o "lembrar", no sentido proustiano, de uma sucessão infinita de imagens que segue o jogo da própria associação, sucessão infinita e por isso sem fim, e sem finalidade (GAGNEBIN, 1999), e o rememorar no sentido desenvolvido por Walter Benjamin, principalmente em "Infância em Berlim por volta de 1900" (BENJAMIN, 1995). Diferentemente do simples lembrar-se, a rememoração é ação consciente e intencional, interrompe o fluxo infinito do que foi em nome do presente, por isso é também uma ação política. “As imagens dialéticas nascem da profusão da lembrança, mas só adquirem uma forma verdadeira através da intensidade imobilizadora da rememoração". (GAGNEBIN, 1999, p.79-80).

Não deu para ignorar aquele encontro, que se tornou uma incômoda lembrança atritando com aquela primeira, confortável e acolhedora. Eu já não estava tão seguro assim do que fazia como professor e começava a desconfiar das minhas boas intenções.

Na ocasião eu participava não só dos espaços de formação fornecidos pela Rede Municipal, mas também de um projeto oferecido pela Unicamp em parceria com a Secretaria Municipal de Educação de Campinas, que envolvia a formação do professor por meio da pesquisa ${ }^{5}$. Mais uma vez me referindo a Larrosa (2014), este projeto visava melhorar a prática docente na perspectiva dos que pensam a educação na relação entre ciência e técnica, como ciência aplicada. De algum modo, de um modo confuso, intuitivo, talvez, combinei

\footnotetext{
${ }^{5}$ O Projeto "Ciência na Escola" teve início em 1996, numa parceria entre o Laboratório de Educação e Informática Aplicada (LEIA), da FE-Unicamp e o Instituto de Física "Gleb Wathagin" (IFGW), que inclui o Centro de Pesquisas em Óptica e Fotônica. A partir de 1997, começou a contar com financiamento da Fundação de Amparo à Pesquisa do Estado de São Paulo - Fapesp, que se estendeu até 2004. Na sua organização e coordenação iniciais, o projeto contou com a participação do $\operatorname{Pr}^{0}$ Carlos Henrique de Brito Cruz, mas a coordenação efetiva esteve, ao menos desde quando ingressei em 1997, com a Prof ${ }^{\mathrm{a}}$ Afira Vianna Ripper, do LEIA. Permaneci no projeto até o final do ano letivo de 2004, mas as atividades continuaram, até porque em 2002 o "Ciência na Escola" começou a fazer parte dos projetos e programas especiais da Secretaria Municipal de Educação de Campinas.
} 
uma suposta prática reflexiva no ensino de História com as sugestões de pesquisa em História inspirada na prática científica do historiador: os meus alunos liam documentos, textos expositivos que descreviam um determinado problema ou evento da história e, a partir de um questionamento, construíam textos de opinião. Eu achava aquela produção de textos uma prática muito significativa para os alunos e para mim também. Este trabalho propunha a formação do professor pesquisador à medida que o aluno aprende por meio da pesquisa (PEREIRA, 2007, pp. 77-88).

Por se tratar de um projeto com financiamento público, eu selecionava e guardava diversas produções dos alunos para fins de escrita de relatórios anuais. Selecionava os melhores, os que eram exemplares em função do que se esperava deles, além disso, havia algo de autoral naqueles textos que justificava o quanto eu os considerava preciosos, que valia a pena guardá-los como um retrato que eu pudesse olhar no futuro, sabe-se lá quando. Nesse momento não estou assim tão seguro se então eu fazia esse julgamento, visto que a memória se dá sempre em função do presente e é essa interpolação infinita naquilo que foi, mas daquela época selecionei e guardei muitas produções e continuei a guardá-las em grandes quantidades nos anos seguintes. Além das lembranças memoráveis e as incômodas, passava agora a colecionar também estas produções exemplares, quase comemorativas do meu trabalho docente.

Daquela época tenho outra lembrança que revela o modo como então eu lidava com essa produção. São lembranças de reconciliação com as minhas nobres intenções após a aparição do faraó menino no Terminal de ônibus. Esta, por sinal, também reteve um acontecimento nesse ambiente de movimento, de passagem.

Eu estava no ônibus a caminho da escola em meados de dezembro. No trajeto, já próximo do meu destino, há uma escola estadual, de ensino médio e fundamental. Tomo esse ônibus sempre no mesmo horário e ele passa em frente 
a essa escola na hora da saída dos alunos do período da manhã. Nesse dia havia uma grande algazarra dos alunos, que arrancavam as folhas dos cadernos e jogavam para o alto, um trecho da rua estava todo tomado pelas folhas brancas, anotadas a tinta azul. Foi então que um menino jogou o caderno embaixo do ônibus e ouviu um xingamento do motorista. Não havia qualquer clima de baderna ou agressão, mas de alegria e festa, como se fosse um ritual de iniciação para que eles pudessem seguir em frente após a destruição das "provas".

É bem possível que eu tenha guardado esse acontecimento na memória porque dialogava com a minha relação com a guarda dos preciosos textos exemplares, tanto que o associei a outro acontecimento, muitos anos depois.

Estávamos também em dezembro, mas desta vez não era uma reunião festiva de aluno, mas um encontro sóbrio de professores reunidos em Conselho na escola onde leciono. Duas colegas conversavam:

- Então, o que vocês fazem com os trabalhos de alunos que não foram entregues? Perguntou a primeira, que era nova na rede municipal e na escola pública a colega ao lado, com a carteira apinhada de diários e avaliações. Achei graça na resposta meticulosa da outra, já "antiga" de escola e de rede municipal:

- Bom, eu faço assim, guardo por dois anos, depois rasgo uma vez ao meio, junto as partes e rasgo novamente, só aí jogo fora.

Achei graça na descrição do "ritual", mas não pelo distanciamento e estranheza, mas muito mais pela familiaridade. Fiz e faço a mesma coisa com os acumulados do ano, depois de separar os que me interessam, os que "valem a pena" serem guardados. No meu ritual de apagar "as provas", espero passar a reunião de Conselho e a reunião de pais. Limpar o armário após esses compromissos institucionais tem um sabor de início de férias, como uma passagem de ano. Mas é claro que muita coisa sobrevive... e se acumula. 
Como se não bastasse tantos "documentos" guardados ou acumulados, em 2008 comecei a produzir e guardar outra modalidade de registro do cotidiano escolar, na forma de narrativas curtas. Na época eu participava do Grupo de Terça do GEPEC (FE-UNICAMP), um grupo aberto à participação de qualquer profissional da escola para debater a educação, num exercício dialógico e de produção de sentidos, até então novidade para mim. Foi nesse ambiente de reflexão sobre a escola pela relação entre experiência e sentido que se desenvolveu um modo muito particular de registro por parte do professor, que foi batizado de "pipocas pedagógicas"6, exercício de escuta atenta e de partilha de experiências, em sentido amplo.

Seguindo as análises e reflexões de LIMA, GERALDI (2015), as "pipocas" são escritos que se enquadram nos recursos narrativos que têm sido utilizados na formação docente e na pesquisa desde fins dos anos 1990. O uso das narrativas busca superar a legitimidade de um único modo de se pensar a produção de conhecimentos em educação que se origina no esforço "científico" em se manter a distância e o não envolvimento do pesquisador com o seu "objeto". Esse modelo ainda hegemônico gerou um conhecimento sobre os processos escolares onde os próprios sujeitos envolvidos não podem se reconhecer, cavou um fosso entre o mundo da vida e o mundo teórico, um mundo que dispensa a existência prática, necessária e responsável dos sujeitos (BAKHTIN, 1993).

Diferentemente de um saber científico abstrato, em que os sujeitos não se reconhecem,

\footnotetext{
${ }^{6}$ Modalidade de escrita de professor que vem se desenvolvendo no Grupo de Terça do Grupo de Estudos e Pesquisa em Educação Continuada (GEPEC) - Unicamp desde 2008. São escritos curtos que descrevem situações da aula/escola e postados numa lista de discussão. Sobre o Grupo de Terça e a escrita das pipocas pedagógicas, ver CAMPOS, PRADO (2013); CUNHA (2010) e NASCIMENTO (2012).
} 


\begin{abstract}
“Uma história contada, ao ser extraída pelo ouvinte do contexto narrado, pode ser recontextualizada em outras situações ou experiências, produzindo novas compreensões entre os contadores e os ouvintes. É isso que confere à narrativa um caráter quase universal (BRUNER, 1998). Ainda que o conhecimento narrativo venha a ser utilizado por outros sujeitos, ele não deixa de ser 'uma experiência situada, idiossincrática, localizada, que participa da natureza dialógica dos indivíduos' (FERREIRA-ALVES; GONÇALVES, 2001, p. 37)". (LIMA; Corinta M. G. GERALDI; João W. GERALDI, 2015, p. 22)
\end{abstract}

Não há um modelo para a escrita das "pipocas", não se trata de um gênero, são registros do cotidiano escolar, geralmente curtos, inicialmente para a troca entre os participantes do grupo, o que gera um potente movimento de troca de experiências e educação mútua do olhar e do escutar.

São escritos que dialogam diretamente com a experiência docente em situação de aula. As reflexões postas nessas "mônadas", assim denominadas por GALZERANI (2013), deslocam o lugar comum, o olhar fossilizado sobre a escola e sobre a aula:

\footnotetext{
“Imagens plenas de contradições e de movimentos de negação de um polo para a sua própria afirmação. Imagens que entrecruzam o ocorrido no passado e o agora da elaboração. E é justamente na agorabilidade, como íntima relação entre o passado, o presente e o futuro - dimensão esta afirmadora do "despertar" no momento presente - que as mônadas, as pipocas têm a potencialidade de serem lidas a contrapelo, ou seja, na direção oposta às relações culturais dominantes, produzindo descontinuidades, rupturas, invenções." (GALZERANI, 2013, p. 88).
}

Eu me coloquei a registrar instantes de aula que geralmente ficariam esquecidos. Registrei, por exemplo, esse ocorrido de sala de aula em 2010 e o nomeei de 


\section{Histórias ${ }^{7}$}

O menino, sentado à minha frente, ainda não havia escrito uma linha sequer e a aula já estava quase acabando.

- Faz o seguinte, deixa estes textos um pouco de ladoos de consulta - e pensa numa história.

- Como assim?

- Conta agora para mim uma história que tenha acontecido com você nestes dias...

- Mas o quê?

- Alguma coisa que tenha acontecido na sua vida, na escola... Alguma coisa diferente.

- É todo dia a mesma coisa.

- Mas você não tem nada para contar? Conta do desfile de 07 de setembro.

- Foi legal...

- Não... conta como foi.

E ele contou.

- Está vendo, você contou uma história. O texto que você vai escrever é parecido, é uma história: tem personagens, acontecem coisas, a história se passa em algum lugar e numa certa época... só que não é o que aconteceu com você. Entendeu?

E ele se pôs a escrever.

Ao lado, a colega também estava com dificuldades. É uma criança miúda e estava recostada na cadeira, com o caderno apoiado na barriga.

- Não consigo escrever, professor.

- Conta aí para mim uma história que tenha acontecido com você nestes dias... - e agachei-me a sua frente.

- Pode ser da minha avó?

- Pode, claro

- A minha tia morreu...

- Nossa, faz tempo?

- Semana passada... Então, né, a minha tia morreu. Aí, a minha avó não podia saber por que ela já tem 92 anos. Aí, a minha tia não sabia como falar para ela, só que ela escutou. Aí a mão dela começou a fazer assim - e imitou o gesto da mão da avó tremendo. A minha avó nunca sai de casa, ela não sai de casa porque ela é velha, tem 92 anos e tem as pernas fracas, mas ela foi ao velório e ficou o tempo todo lá, ao lado do corpo da

\footnotetext{
${ }^{7}$ Escritos de Professor: Reflexão sobre a prática/Pipoca pedagógica/2010.

Esta e as próximas "pipocas pedagógicas" aqui citadas, seguem a identificação acima por conta do modo como foram organizadas e arquivadas como documentos de pesquisa.
} 
minha tia. Ela nunca sai de casa, mas foi lá no velório repetiu, com uma tristeza tão profunda que me comoveu.

A história da menina desestabilizou o meu procedimento, a minha experiência acumulada.

- Então, você percebeu? Você acabou de contar uma história. Agora é só fazer a mesma coisa sobre a guerra que o Governador Geral fez contra os Tupinikins da Bahia no século XVI. Você consegue?

- Vou contar só o que eu sei. Pode?

Na mesma época em que produzia, trocava e guardava esses registros de aula, inicie uma investigação da minha prática docente problematizando a escrita de textos pelos alunos, procurando desvelar e compreender o que se passava na aprendizagem de História que considerava, além dos textos didáticos expositivos, o uso de documentos, o diálogo e, como avaliação do aprendido, a produção de textos de opinião em torno de uma questão préformulada pelo professor ou construída coletivamente a partir dos sentidos produzidos durante as discussões.

Para essa investigação tomei os escritos e outras produções de aluno como documentos, os muitos textos exemplares que eu havia guardado, na articulação com os meus próprios registros de aula, as pipocas pedagógicas, além das muitas lembranças desses anos todos de docência.

Quando fui inventariar os meus guardados ${ }^{8}$ me dei conta que analisar apenas as produções significativas, de construção de argumentos e de opinião exemplares, dificultava a emergência de relações outras por mim não sabidas, visto que eram produções construídas de modo muito semelhante que apenas me confirmavam. Por sorte do acaso, havia também uma quantidade bem maior de textos que não se enquadravam, que sobreviveram aos "rituais de eliminação das provas", uma quantidade enorme de produções de aluno que

\footnotetext{
${ }^{8}$ No Grupo de Estudos e Pesquisa em Educação Continuada (GEPEC - FE, Unicamp), a produção dos dados de pesquisa a partir dos "guardados" relaciona-se com as metodologias das investigações narrativas que têm sido produzidas naquele grupo de pesquisa, e pode ser conferido em MORAIS, PRADO (2011).
} 
por diversas razões não foram entregues e foram se acumulando no meu armário e que, por sorte, não foram dobrados duas vezes antes de serem rasgados e jogados fora. O tipo de material que precisa ser esquecido, seja pela sua monotonia, reflexo dos processos absurdamente burocráticos e administrados da escola, seja por sua qualidade, repositório de erros dos alunos, que nada mais são do que a exposição de verdades outras do que se passa na sala de aula. Entre eles estavam produções de cerca de oitenta alunos entre 2008 e 2011, produções de diversas naturezas e sem qualquer pré-seleção, o que possibilitava reconstruir os processos de aprendizado de história dessa turma.

À medida que lia e categorizava as produções, uma problemática acabou se configurando: o ensino de história dialogada - onde por meio da escrita de textos os alunos possam construir ou mesmo reproduzir opiniões e impressões construídas durante as discussões - favorece a percepção da aula enquanto experiência? Essa questão dialogava com as reflexões de BENJAMIN (1994) e LARROSA (2001), a partir de dois ensaios, "Experiência e Pobreza" e "O Narrador", que foram escritos por Benjamin quase que paralelamente no início dos anos 30 .

No primeiro texto, Benjamin desenvolve a sua noção de experiência tradicional, de Erfahrung, de saber compartilhado em uma determinada sociedade, e lamenta que esse tipo de experiência já não exista mais no mundo moderno: "Primeiro, a experiência se inscreve numa temporalidade comum a várias gerações. Ela supõe, portanto, uma tradição compartilhada e retomada na continuidade de uma palavra transmitida de pai para filho [...]" (GAGNEBIN, 1999, p. 57). Benjamin articula a sua ideia de experiência com a de narração. Para ele, a arte de contar se perdeu porque a experiência tradicional já não existe mais. Não há mais a possibilidade da experiência em comum e da palavra em comum. 
Os dois textos citados, quando estudados em sua articulação, refutam uma interpretação bastante difundida de Benjamin enquanto um autor saudosista, que permanece apenas na lamentação da perda da experiência e da palavra comum das sociedades artesanais. Se essa impressão fica patente em "Experiência e Pobreza", "O Narrador", por outro lado, aponta para outras possibilidades de contar a história, "que saberia rememorar e recolher o passado esparso sem, no entanto, assumir a forma obsoleta da narração mítica universal, aquilo que Lyotard chamará de as grandes narrativas legitimantes." (Idem, p. 62).

Essas considerações acerca das possibilidades da experiência enquanto Erfahrung e, portanto, da narrativa, são retomadas por LARROSA, em especial no texto "Notas sobre a experiência e o saber de experiência", de 2014. Para este autor:

\begin{abstract}
“A experiência é o que nos passa, o que nos acontece, o que nos toca. Não o que se passa, não o que acontece, ou o que toca. A cada dia se passam muitas coisas, porém, ao mesmo tempo, quase nada nos acontece. Dir-se-ia que tudo o que se passa está organizado para que nada nos aconteça. Walter Benjamin, em um texto célebre, já observava a pobreza de experiências que caracteriza o nosso mundo. Nunca se passaram tantas coisas, mas a experiência é cada vez mais rara." (LARROSA, 2014, p.
\end{abstract} 18)

Trata-se, portanto, não de recuperar o modo tradicional de se narrar, visto que a experiência tradicional é cada vez mais rara (e talvez impossível), mas de manter o olhar e a escuta atentos para outros modos de experimentar o mundo, de ser tocado por ele, e arriscar novos modos de contar.

Havia, na produção de alguns alunos, indícios que apontavam para um modo de aprender história que os afetava, que os deslocava, como esse fragmento, em que o aluno faz considerações sobre a independência política de 1822 que redimensiona a sua experiência com o tempo presente: 


\section{Independente sim, livre não!}

Eu acho que foi boa a independência do Brasil, mas os únicos problemas foram a escravidão e a monarquia também. Não tem como um país ter liberdade se a maioria da população é escravizada, e a monarquia atrasou muito o desenvolvimento do Brasil, eu acho que se a população fizesse uma grande rebelião enquanto o Brasil era uma colônia, não teríamos o período da monarquia brasileira e teríamos se tornado uma república, e assim com certeza o Brasil de hoje seria muito mais desenvolvido. ${ }^{9}$

A fim de demonstrar um pouco mais essa possibilidade vou precisar fazer um pequeno desvio na exposição desses fragmentos tanto no tempo quanto no espaço e trazer um texto escrito em 2006. Já era final de ano, naqueles dias que os alunos já não "aparecem" mais na escola e a gente aproveita para organizar os diários, corrigir avaliações etc. Numa tarde dessas, recebi a visita de uma aluna da oitava série que passou por lá para se despedir, visto que no próximo ano ela iria para o ensino médio. Ela então me entregou um texto - que eu não havia solicitado - como se fosse uma carta, um presente. Nessa carta/presente aluna relata o quanto aquele ano havia sido "proveitoso", o quanto todas as discussões a haviam ajudado "e muito a entender o que se passa no Brasil hoje":

Antes desse ano iniciar-se não entendia nada de política, de Democracia, de Capitalismo, de Nazismo, Fascismo, NaziFascismo, Comunismo, Socialismo, Ditadura. [...]Depois da "empurradinha" do professor para entender esses assuntos, me interessei mais em tudo isso, toda essa questão política, e comecei a buscar informações por fora das aulas, procurei saber mais sobre o Nazismo, li revistas, livros sobre o assunto, sobre

\footnotetext{
${ }^{9}$ Escritos de Aluno: Texto de opinião/Independência política/avaliação/2010

Esta e as próximas citações de textos de aluno, tomados como documentos de pesquisa, serão indicadas de acordo com o modo como foram classificados e organizados enquanto arquivo.
} 
até mesmo o Anarquismo. Hoje em dia me deparo a discutir (de maneira saudável é claro) com meu pai, tios sobre esses assuntos, tentando achar uma explicação para o que está ocorrendo com o Brasil atualmente, sem contar que é muito prazeroso chegar e contar essas histórias (da Ditadura, dos golpes, dos governos, etc.) para alguém e ela contestar dizendo outra coisa, e você também acrescentar algo, com a sua opinião sobre o assunto. ${ }^{10}$

Novamente o que se vê, nesse documento, é o depoimento de alguém que se tornou outro no mundo a partir de uma experiência de sala de aula, deslocamento não só em relação ao redimensionamento do presente coletivo, mas também subjetivamente, no seu devir como adolescente na relação com a autoridade dos adultos na família.

Em outro momento do meu hábito de arquivar produções de aluno, esses textos certamente seriam guardados como testemunhos, não teriam o destino comum do ritual de dobrar duas vezes, rasgar e jogar fora. Mas dessa, as produções 'exemplares' de apenas cinco alunos estavam na companhia de todos os alunos da turma, num total de oitenta.

A maioria apenas reproduzia mecanicamente os objetivos da aula, reproduzia partes dos documentos que eu apresentava e produzia as opiniões como conclusão na finalização do texto, como simples comentário. Eram produções construídas corretamente, de acordo com o que fora ensinado, mas sem qualquer envolvimento do aluno, sem qualquer indício que vinculasse o aprendido à vida. O próximo fragmento é de uma avaliação sobre a importância - ou não - do aprendizado de história, de autoria de um desses alunos:

Sei lá, eu acho a matéria legal, mas não a melhor. Com a maior seriedade não acho importante a aula de história, pois não sei o que a história vai me ajudar.

${ }^{10}$ Escritos de Aluno: Texto de opinião/Ditadura militar/Aulas de História/2006. 
Para mim a matéria de história quer dizer como era antigamente, o que aconteceu antigamente, e como funcionava antigamente o mundo. Pra mim isso só vai ser útil para contar para meus filhos, ou senão para contar para meus alunos. Mas não sou ninguém para julgar alguém.

Mas tenho que estudar para saber o que vai me ajudar ou vai ser útil para mim. Bola pra frente que a vida continua. Tenho que estudar muito para entender melhor.

Só queria acrescentar que muitas pessoas não querem conhecer melhor o mundo, pois para nós não julgar ninguém. ${ }^{11}$

Para ele, a história se resumia a isso, ao conhecimento do passado pelo passado, serviria, no máximo, para ser professor ou contar para os filhos. Ao mesmo tempo admite que ainda é muito jovem para julgar, que precisa estudar mais para saber da utilidade ou não desse conhecimento, mas, contraditoriamente, afirma que um conhecimento melhor do mundo não lhe interessa, e termina com uma estranha justificativa moral, que se deve viver no mundo sem julgar ninguém.

Este texto cauteloso indica movimentos da produção da aula que não estavam e não estão dados para a minha consciência. Entre as "pipocas pedagógicas", tem uma escrita em 2013, que pode indicar os modos possíveis dessa educação de sentido negativo, uma valorização da forma em prejuízo da vida. Chamei-o de

Aranhas ${ }^{12}$

Eu estava em pé, junto às primeiras carteiras, orientando as atividades. As crianças do sexto ano estavam com os olhos fixos em mim:

- Uma aranha!! Disse alto um menino.

Era uma dessas miudinhas, descendo por seu fio quase invisível, bem à minha frente. Enrolei o texto que tinha nas mãos e passei logo acima dela, que caiu e tentou se esconder, mas eu fui mais rápido e a esmaguei com o pé. Ficou só uma

\footnotetext{
${ }^{11}$ Escritos de Aluno: Texto de opinião/Aulas de História/Avaliação do professor/2010

12 Escritos de Professor: Reflexão sobre a prática/Pipoca pedagógica/2013.
} 
manchinha úmida no chão. Foi tudo muito rápido, nem deu tempo de causar qualquer reação na sala.

Estava com pressa e preocupado porque os alunos não estavam entendendo a proposta. Fui à lousa e copiei novamente os dois enunciados que eles tinham no caderno, simulei os textos respostas com linhas e enumerei em sequência: resposta 1 e resposta 2.

- Estão vendo? Agora é só você juntarem as duas respostas para formar um único texto - e fiz uma seta. Mas antes, é preciso inventar um parágrafo para ligar um texto no outro.

Ficou bonita a organização gráfica na lousa, quase um dégradé da disposição espacial deles na sala. Tudo muito limpo, racional e previsível.

- Se vocês não conseguirem fazer, depois a gente pode tentar um diferente.

- Professor, posso fazer outro, sem usar as duas respostas?

- E se ninguém conseguir fazer, o senhor vai dar nota mesmo assim?

- Posso contar o que aconteceu com a minha tia?

- Professor? É texto ou é resposta?

Fiquei exasperado com tantas dúvidas, eram muitas "aranhas" descendo pelo teto ao mesmo tempo.

Não há como prever as coisas da vida, que vive por sobressaltos, por isso todo novo instante é um momento de risco e de perigo. Nesse sentido, a aranha que esmaguei tinha mais coragem. Pensando bem, talvez não, até porque ela, a aranha, não sabe o quanto é confortável viver num mundo de coisas prontas para serem repetidas - se soubesse não deixaria nunca a segurança da teia que tece sempre do mesmo jeito. Dessas coisas só sabem aqueles que podem fazer escolhas: nós professores - e outros seres pensantes.

Além dessa maioria, que do meu ponto de vista realizava as atividades como simples tarefa, estavam ainda aqueles que "não aprendiam", que não respondiam minimamente aos objetivos. Entre eles estava um aluno que por três anos seguidos eu avaliei a sua aprendizagem em História muito aquém do esperado.

Vou reproduzir um dos textos que ele escreveu quando estava no sexto ano. Para escrevê-lo ele tinha dois documentos, uma carta escrita pelo 
governador Men de Sá no século XVI, relatando uma guerra contra os tupiniquins da Bahia, e um trecho de texto de Gandavo contando do despovoamento do litoral. ${ }^{13}$

No litoral Brasileiro, avia muitas pessoas que eram sacrificadas ao trabalho.

Um dos dominadores era bárbaro gentio que era um homem mal bravo sem espirito de boas intenções e agilidade, os trabalhadores ou eram sacrificados ou fugiam para montanhas e colinas.

No começo avia muitos índios isso não facilitava que os portugueses ganhasse aquela terra toda, porque eram muitas tribos indígenas que juntaram para fazer guerra contra os portugueses.

A tribo dos tupiniquins, não sabia se estava ajudando os portugueses ou se estavam atrapalhando a vida da tribo ou do português porisso na minha opinião eles devião fazer guerra contra os portugueses para que a tribo tupinikin e outras aldeias indígenas ficassem com mais espaço e fossem os que mandassem na américa latina.

Os portugueses fiseram proposta aos índios que se ele trabalhasse para nós os portugueses trocaria o trabalho por ferramentas coisas sem valor.

Os indios asseitaram e começaro a achar ouro prata e o pal brasil e colocaram no navio tudo que tem de valor e os portugueses votaram a Portugal.

Eu entendi que os portugueses vieram buscar coisas de muito valor e de riquezas, eles trocaram as coisas por coisas sem valor. ${ }^{14}$

A carta redigida pelo Governador Geral faz uma descrição muito precisa e restrita: os indígenas de Ilhéus atacaram os colonos e enfrentaram a força do governo. Com a vitória dos colonizadores os índios foram obrigados a reconstruir os engenhos e a pagar tributos. É basicamente isso que diz o documento, mas ele interfere em toda a narração, procura dar-lhe marcos mais de acordo com a estrutura de uma fábula. A começar pelo tom de quase "era

\footnotetext{
${ }^{13}$ Coletânea de doc. Históricos para o $1^{\circ}$ grau. CENP, SE, São Paulo, 1978. p. 13 - 14.

${ }^{14}$ Escritos de Aluno: Narrativa/Conquista do litoral/Avaliação/2008
} 
uma vez...." com eu ele inicia o texto: "No litoral Brasileiro, avia muitas pessoas que eram sacrificadas ao trabalho", em seguida faz uma inversão de termos: "bárbaro gentio", nos documentos, é como Gandavo identifica os indígenas, o aluno, no entanto, toma a palavra bárbaro para caracterizar os "dominadores", a ponto de criar um personagem novo para a trama: "um homem mal bravo sem espirito de boas intenções e agilidade". A guerra tomou a partir daí proporções colossais - ao menos enquanto possibilidade - pois se todas as tribos se unissem contra os conquistadores "seria uma guerra emocionante" e quem sabe, hoje os indígenas mandariam na América Latina. Em seguida ele cumpre a necessidade de dar um fim mais convincente e completo para essa história, e para isso ele fez associações com conhecimentos anteriores, que ele obteve no quarto ou quinto ano. E é o que ele faz quando diz que os portugueses fizeram proposta para que os índios trabalhassem em troca de objetos de pouco valor, "colocaram no navio tudo que tem de valor e os portugueses votaram a Portugal".

Essa foi a primeira versão do texto, que provavelmente foi lido por outros colegas antes da escrita definitiva ${ }^{15}$, esta sim para ser avaliada por mim. Ao que parece, os colegas gostaram do que leram, pois ele fez poucas alterações na segunda versão, a mais significativa foi logo no início:

No litoral Brasileiro, avia muitas pessoas que eram sacrificadas ao trabalho. Um dos dominadores sempre se chamava de Barbaro gentio que era um homem mal sem espirito de boas intenções e uma agilidade incriveu, os trabalhadores ou eram sacrificados ou fugiam para montanhas e colinas.

Ele não só manteve a recriação dos documentos em fábula como corrigiu e reforçou algumas marcas nesse sentido, quando o "bárbaro gentio" se torna Barbaro, nome de um dos personagens dessa história de guerras e de

\footnotetext{
${ }^{15} \mathrm{~A}$ primeira versão do texto era trocada entre os colegas para uma primeira leitura, quando discutiam e apontavam melhoras e correções nos textos entre si. Geralmente eu recolhia as duas versões para compreender melhor as escolhas e a estruturação do texto.
} 
conquistas. E corrigiu uma possível interpretação equivocada do leitor de que o tal Barbaro não tivesse agilidade alguma, como pode dar a entender este trecho da primeira versão: “Um dos dominadores era bárbaro gentio que era um homem mal bravo sem espirito de boas intenções e agilidade". Na segunda versão ele acrescenta que o Barbaro tinha sim, uma "agilidade incrível", tornando-o um vilão ainda mais aterrorizante.

Eu invalidei o texto desse aluno - e quase todos os outros que ele escrevia - não só pela sua construção como história "fantástica", mas também pelas suas informações erradas e fora de lugar, a mais evidente, no nosso exemplo, quando ele transformou a expressão "bárbaro gentio", que constava nos documentos históricos, em um personagem chamado Barbaro. No contexto dos documentos, e do século XVI, "gentio" era o termo usado pelos colonizadores em relação aos índios, que deviam ser conquistados por conta da sua barbárie. O menino, porém, inverte essas nomeações e bárbaro passa a ser o colonizador, enquanto os índios são transformados nos "sacrificados ao trabalho".

De qual outro modo nos é possível compreender os escritos do meu aluno nessa outra perspectiva de linguagem, sem a sua classificação como aluno "fraco", "imaturo" e outros adjetivos justificadores do nosso ponto de vista racionalmente iluminista e iluminado? O meu aluno, então por volta dos onze anos, estava ainda muito próximo da infância, nesse território de passagem que Benjamin chama de limiar, por isso se permitia jogar um jogo secreto, um quebra-cabeças misturando as peças fantásticas da fantasia com as noções e as informações polidas que eu lhe apresentava. E o que é isso, senão a criação poética?

Num dos fragmentos do seu Projeto das Passagens, Walter Benjamin afirma a diferença entre estes dois termos: 
Ritos de passagem - assim se denomina no folclore as cerimônias ligadas à morte, ao nascimento, ao casamento, à puberdade etc. $\mathrm{Na}$ vida moderna, estas transições tornam-se cada vez mais irreconhecíveis e difíceis de vivenciar. Tornamonos muito pobres em experiências liminares. [...] $\mathrm{O}$ limiar (Schwelle) deve ser rigorosamente diferenciado da fronteira (Grenze). O limiar é uma zona. Mudança, transição, fluxo [...] (BENJAMIN, Passagens, p. 535 in GAGNEBIN, 2010, p. 12)

Comentando esta definição, BARRENTO observa que "a fronteira é muitas vezes apenas um lugar burocrático, o limiar é um lugar onde fervilha a imaginação" (2012, p. 47). O meu aluno experimentava a sua passagem para a adolescência como limiar, mas eu o tratei como fronteira, e fiz isso com a segurança de quem responde por um projeto a zelar, por uma determinada concepção de aluno, de conhecimento e de escola que não são mais do que isso mesmo que enunciam: concepções.

Do mesmo modo que a narrativa de aula "Aranhas", atrita dialogicamente com a produção supostamente burocrática dos alunos, trago agora a pipoca pedagógica que dialoga com os modos de aprender do meu aluno fabuloso, chamei-a de

\section{Ogros, caçadores de mamutes e outros seres fabulosos ${ }^{16}$}

Demorei um pouco para entender a pergunta da menina do sexto ano, em pé ao meu lado:

- E ogro, existe?

- Não, claro que não. Ogro é uma fantasia, igual ao SaciPererê e a Mula-sem-cabeça. Por que você está perguntando, tem medo?

- Não, é que eu pensei que existia.

Voltou para a carteira, mas retornou quase em seguida:

- Se uma pessoa nasce nos Estados Unidos e logo depois vem para o Brasil, ela vai falar inglês ou brasileiro?

\footnotetext{
${ }^{16}$ Escritos de Professor: Reflexão sobre a prática/Pipoca pedagógica/2009
} 
- Vai falar português - brasileiro - porque a língua a gente aprende. Os bebês não nascem falando, não é verdade? Mas porque você está perguntando isso?

- Nada não, é que a patroa da minha tia é dos Estados Unidos, e quando as meninas vêm para cá, elas falam inglês, espanhol, português...

- Mas é porque elas estudaram, aprenderam na escola.

-Ah!tá! - respondeu como se não estivesse totalmente convencida, assim meio que decepcionada com a resposta.

Fiquei pensando sobre as perguntas da menina, tentando estabelecer algum nexo com o que estávamos estudando.

Eles estavam lendo sobre a ocupação pré-histórica do continente americano, coisa de onze mil anos atrás: leram sobre "pontes" de gelo ligando a América à Ásia, sobre glaciação e caçadores de mamutes na América do Norte. Eles também haviam estudado sobre o bicho-preguiça gigante que habitava o Brasil e sobre os ossos fossilizados de uma mulher pré-histórica de Minas Gerais, batizada pelos cientistas de "Luzia".

Agora vejo que não deveria ter respondido tão categoricamente que ogros não existiam. Poderia ter dado uma resposta diferente, pois vai saber: há onze mil anos pode muito bem ter ocorrido um encontro entre ogros e caçadores de mamutes, numa ponte de gelo perdida no tempo. Pensando melhor, esta história só poderia ser contada de verdade pelas crianças norte-americanas que falam três línguas, pela Luzia que então estava viva -, ou por outro ser fabuloso qualquer. Eu, Professor de História, não poderia jamais fazê-lo porque compliquei demais o tempo, a ponto de esvaziá-lo totalmente dessa sofisticação pela simplicidade que é a fantasia.

Como foi dito anteriormente, segundo Gagnebin, Benjamin não "resolveu" a questão de como construir outra narrativa, apropriada aos tempos que correm, mas esboçou "algumas pistas, algumas vias de aproximação", que a autora se propõe a explorar: a definição e relação com o "conselho verdadeiro" e a ligação entre as percepções sobre a morte e narração. Para os nossos propósitos interessa a primeira via de aproximação, a de definição de verdadeiro conselho. Segundo ela, "Benjamin não define os atos de dar ou receber um conselho por suas características psicológicas ou paradigmáticas, mas, muito claramente, por sua especificidade narrativa" (p. 63), pois, segundo o próprio autor, “O conselho é de fato menos uma resposta a uma pergunta do 
que uma proposta que diz respeito à continuidade de uma história que se desenvolve agora." (Benjamin, p. 59, Apud. GAGNEBIN). Nesse sentido,

O conselho só pode ser, portanto, dado se uma história conseguir ser dita, colocada em palavras, e isso não de maneira definitiva ou exaustiva, mas, pelo contrário, com as hesitações, as tentativas, até as angústias de uma história "que se desenvolve agora", que admite, portanto, vários desenvolvimentos possíveis, várias sequências diferentes, várias conclusões desconhecidas que ele pode ajudar não só a escolher, mas mesmo a inventar, na retomada e na transformação por muitos de uma narrativa à primeira vista encerrada na sua solidão. (GAGNEBIN, 1999, p. 63)

Essa continuidade nada mais é que as muitas interpretações que tais histórias permitem, e esse é o "verdadeiro conselho", a interpretação que o leitor dá a história que ouve, lê, e inventa, a partir daí, novas possibilidades, novos entendimentos, novos sentidos sobre o mundo narrado. Não se trata, portanto, de processos de transmissão.

Por outro lado, se o conselho não está essencialmente nos conteúdos produzidos, mas nas interpretações possibilitadas pelas brechas de um discurso que não se quer totalizador e acabado, mas consciente de sua abertura ao outro nos processos de compreensão e interpretação, isso só se torna possível se assumimos a concepção de que nos constituímos em processos alteritários, e é nesse território de passagem, nesse espaço de limiar, que tais reflexões se articulam àquelas desenvolvidas por BAKHTIN sobre o ato responsável (2010), particularmente em torno das possibilidades e dos modos dos eventos únicos e concretos da vida, das singularidades, de serem enunciadas em sua verdade.

Alertei no início dessa narrativa que se tratava de uma curta viagem, melhor seria dizer que se trata de uma viagem de curtas paradas, mas que se prolonga sem chegar ao seu destino. Do mesmo modo, também não é um retorno para casa. Passamos pelas minhas rememorações de professor nos 
primeiros anos de docência com suas expectativas e promessas, nos detivemos num porto aprazível, lugar confortável dos alunos que falavam a minha língua e eu me sentia em casa, depois atracamos em uma terra mais árida, mas populosa, e travei conversa com alunos que me respeitavam, mas não se sentiam atraídos pelas histórias que eu contava, para, finalmente aportar em uma ilha de contadores de histórias, mas numa língua que eu não entendia. Mas "Bola pra frente, que a vida continua. Tenho que estudar muito para entender melhor", parafraseando o aluno cauteloso que não tinha interesse pelas minhas histórias.

\section{Devir}

- Essa reportagem é do ano 2000...

Mal terminei a frase e ouvi alguns comentários de espanto, do tipo: "nossa!!"

A reportagem tratava da pré-história americana. Os alunos do sexto ano têm por volta de 11 anos de idade.

- Gente, por favor. Esse texto foi escrito no ano 2000, faz pouco tempo. As explicações que ele traz são do presente, são de hoje em dia ainda.

- Então, se esse texto do passado é do presente considerou com seriedade uma menina - o que se escreve agora é do futuro?

- É....pode ser - respondi de modo evasivo, mas com rapidez, como que desviando de uma seta mortal lançada pelo tempo em sentido contrário.

Do passado, sabemos tão somente que passou; o futuro, este se apresenta como promessa; o presente, por conta dessa promessa a ser cumprida - ou não - só pode ser o compromisso de agora. E o nosso compromisso de agora é a menina que se espanta com o devir, palavra que ela ainda desconhece.

\section{Referências bibliográficas}

BARRENTO, João. Walter Benjamin: limiar, fronteira e método. Olho d'água, São José do Rio Preto, 4(2): 1-115, Jul. - Dez./2012. Disponível em: < 
http://www.olhodagua.ibilce.unesp.br/index.php/Olhodagua/article/viewFile/1 46/168>. Acesso em: 24 de julho de 2013.

BAKHTIN, M. M. Para uma filosofia do Ato Responsável. [Tradução aos cuidados de Valdemir Miotello \& Carlos Alberto Faraco]. São Carlos: Pedro \& João Editores, 2010.

BENJAMIN, W. Infância em Berlin por volta de 1900. In: Rua de mão única. Obras escolhidas, v. II. Trad. Rubens R. Torres Filho e José Carlos M. Barbosa. $5^{\mathbf{a}}$ ed., São Paulo: Brasiliense, 1995. pp. 71-142.

O narrador - Considerações sobre a obra de Nikolai Leskov. In: Magia e técnica, arte e política. Ensaios sobre literatura e história da cultura. Obras escolhidas. Vol. I. São Paulo: Brasiliense, 1994, pp. 197-221.

Experiência e pobreza. In: Magia e técnica, arte e política. Ensaios sobre literatura e história da cultura. Obras escolhidas. Vol. I. São Paulo: Brasiliense, 1994, pp. 114-119.

CAMPOS, Cristina Maria; PRADO, Guilherme do Val Toledo. (Org.) Pipocas pedagógicas: narrativas outras da escola. 94 p. São Carlos: Pedro \& João Editores, 2013.

CUNHA, Glória Pereira. Sonoridades do sul: ausências, emergências, traduções e encantaria na educação. 267 p. Dissertação (Mestrado em Educação) - Faculdade de Educação, Universidade Estadual de Campinas, 2010.

FREIRE, Paulo. Educação e mudança. Trad. De Moacir Gadotti e Lilian Lopes Martin - Rio de Janeiro: Paz e Terra, 1983.

GAGNEBIN, Jeanne Marie. História e narração em W. Benjamin. $2^{\underline{a}}$ ed. São Paulo: Perspectiva, 1999.

Walter Benjamin ou a história aberta. In Walter Benjamin - Magia e técnica, arte e politica - Ensaios sobre literatura e História da cultura. Obras escolhidas V. I. Tradução de Sergio Paulo Rouanet, $7^{a}$ ed., São Paulo: Brasiliense, 1994.

Limiar, aura e rememoração - Ensaios sobre Walter Benjamin. São Paulo: Editora 34, 2014. 
GALZERANI, M. C. Bovério. Contar a aula, reencantar a escola, (re)inventar a escola, (re)inventar a imagem de produção de saberes docentes. In. CAMPOS, Cristina Maria; PRADO, Guilherme do Val Toledo. (Org.) Pipocas pedagógicas: narrativas outras da escola. São Carlos: Pedro \& João Editores, 2013. pp. 83-94.

LARROSA, J. Pedagogia profana - danças, piruetas e mascaradas. $4^{\mathrm{a}}$ ed., trad. Alfredo Veiga-Neto, Belo Horizonte: Autêntica, 2004.

Tremores. Escritos sobre experiência. Belo Horizonte: Autêntica, 2014.

LE GOFF, Jacques. A História Nova. Tradução por Eduardo Brandão, $4^{\mathrm{a}}$ ed., Martins Fontes: São Paulo, 2001.

LIMA, Maria Emília C.de C.; GERALDI, Corinta M.G.; GERALDI, João W. O trabalho com narrativas na investigação em educação. Educação em Revista, Belo Horizonte, v.31, n.01, p.17-44, Janeiro -Março 2015. Disponível em: https://www.scielo.br/scielo.php?script=sci arttext\&pid=S0102$\underline{46982015000100017 \& \operatorname{lng}=\mathrm{pt} \& \mathrm{nrm}=\mathrm{iso \& t} \operatorname{lng}=\mathrm{pt}}$

MORAIS, Jacqueline de F. S.; PRADO, Guilherme do Val Toledo. Inventário organizando os achados de uma pesquisa. EntreVer, Florianópolis, v. 01, n.01, p. 137-154, 2011. Disponível em:

https://periodicos.ufsc.br/index.php/EntreVer/article/view/34202

NASCIMENTO, Maria José Oliveira et al. Sobre pipocas, sensibilidades e cotidiano escolar: Gepec. LEITURA: TEORIA \& PRÁTICA (SUPLEMENTO), n.58, jun.2012. Disponível em <http://alb.com.br/arquivomorto/edicoes anteriores/anais18/pdf/1tp 58 suplemento 18cole 1602 1999.pd f $>$ Acesso em: 11 de agosto de 2014 .

OTTE. Georg; SEDLMAYER. Sabrina; CORNELSEN. Elcio (Orgs). Limiares e passagens em Walter Benjamin. Belo Horizonte: Editora UFMG, 2010.

PEREIRA. Marcemino Bernardo. Constituição do professor pesquisador a partir do aluno pesquisador. In: VARANI. Adriana; FERREIRA. Cláudia R.; PRADO. Guilherme do Val Toledo (Orgs). Narrativas Docentes - Histórias de trabalhos pedagógicos. Campinas, SP: Mercado de Letras, 2007, p. 77- 88.

Múltiplos projetos: produção de vida variada no ofício de professor. Dissertação (Mestrado em Educação) - Universidade Estadual de Campinas, 
2008.

Disponível

em:

http://repositorio.unicamp.br/bitstream/REPOSIP/251994/1/Pereira Marcemino Bernardo M.pdf

"Faço-me das tuas nas nossas palavras": a escrita de textos no

ensino de História. Tese (Doutorado em Educação) - Universidade Estadual de Campinas, 2014. Disponível em: http://repositorio.unicamp.br/bitstream/REPOSIP/254084/1/Pereira Marcemino Bernardo D.pdf

SEDLMAYER. Sabrina; GINZBURG. Jime (Orgs.) Walter Benjamin - Rastro, aura, história. Belo Horizonte: Editora UFMG, 2012.

TESSITORE, Viviane. Arquivos, centros de documentação e de memória: perfis institucionais e funções sociais. In: CAMPOS, José F. Guelfi (Org.) Arquivos Pessoais - experiências, reflexões, perspectivas. Associação de Arquivistas de São Paulo. São Paulo: ARQ-SP, 2017. (Eventus 4). p. 12-28. 